\title{
КООПЕРАЦИЯ В КОНТЕКСТЕ СТРАТЕГИИ ОБЩЕСТВЕННОГО РАЗВИТИЯ
}

\author{
(c) 2019 Егоров Владимир Георгиевич \\ доктор исторических наук, доктор экономических наук, \\ профессор РЭУ им. Г.В. Плеханова, профессор МГТУ им. Н.Э. Баумана, \\ заместитель директора Института стран СНГ, Россия, Москва \\ E-mail: korrka@mail.ru \\ (c) 2019 Кузнецов Алексей Владимирович \\ кандидат исторических наук, \\ доцент кафедры политической экономии и истории экономической науки \\ РЭУ им. Г.В. Плеханова, Россия, Москва \\ E-mail: isikuzav@mail.ru \\ (c) 2019 Иншаков Андрей Алексеевич \\ аспирант кафедры Политической экономии и истории экономической науки \\ РЭУ им. Г.В. Плеханова, Россия, Москва \\ E-mail: aero789@mail.ru
}

Статья посвящена теоретическому анализу сущностных качеств социальной рыночной экономики. Воплощая в себе идеи солидаризма, она создает наиболее благоприятные условия для развития кооперации всех видов и форм. Показано, что государство в системе нового хозяйственного порядка должно трансформироваться в субъект рыночной экономики, выступая институтом, гармонизирующим общественные, групповые и индивидуальные интересы и создавая «механизм открытого доступа» к факторам производства для всех акторов хозяйственной деятельности. Выявлены характерные черты кооперативной формы собственности.

Ключевые слова: сущностные качества кооперации, противоречивая природа кооперации, кооперативная собственность, теория солидаризма, социальная рыночная экономика, государственная кооперативная политика, посткапитализм, малые формы хозяйствования.

Финансирование: Работа выполнена в рамках реализации гранта РФФИ 18-010-00437 «Кооперация как инструмент развития сельских территорий и экономической самоорганизации населения», договор № 18-010-00437\19 от «14» марта 2019 г.

Кооперация как форма социально-экономической организации стала одним из направлений, инициированной рынком, потребности мелкого производства к концентрации и разделению труда при переходе общества к индустриальной формации.

В отличие от капиталистических форм, институализировавшихся посредством революционного отрицания традиции, кооперирование мелких товаропроизводителей развивалось эволюционно, сохраняя преемственность прежнему порядку. В силу этого кооперация, безусловно, органичная сущность модерна, имеет дуалистичное качество. С одной стороны, являясь феноменом рыночной экономики, ориентиро- ванным на получение прибыли, с другой стороны, представляет собой сущность, сохраняющую конструктивное содержание традиции в модернизационном процессе, в качестве природных черт, заимствованных из прежнего социальноэкономического порядка.

Конечно, качества, заимствованные из традиционного порядка, не оставались статичными и трансформировались под действием рынка. Например, присущий коллективным объединениям прошлого эголитаризм замещается принципами распределения дохода в соответствии с величиной пая, количеством и качеством трудового участия. Вместе с тем традиционное основание остается «фундаментом» внутреннего 
строя кооперации и определяет ее природное отличие от институтов капитализма.

Имея отправным «пунктом» развития частную собственность, кооперативные объединения продуцируют принципиально иной кооперативный вид собственности, отрицающий эгоистическое целеполагание личности к обогащению, но базирующийся на стремлении кооператоров к ее приумножению как единственному средству стабильности товарного производства.

Кооперативная собственность обладает эмерджентными свойствами, отличными от простого сложения трудовых и материальных средств ее участников. Одной из ее характеристик является преодоление отчужденности работника от результатов труда, достигаемое за счет гармонизации интересов трудящегося и собственника. Отечественный теоретик кооперации А. Исаев по этому поводу писал: «отводя каждому в деле правления такую же совокупность прав, как всем остальным, артель в своих экономических отношениях руководствуется наличием относительного равенства. Артель стремится к тому, чтобы все члены исполняли в экономической жизни союза одинаковые обязанности и, поскольку такая цель достигается, постольку все участники пользуются равными правами при распределении выгод, проистекающих из артельного предприятия. Равенство обязанностей в экономической жизни союза проявляется в том, что каждый член посвящает артели столько же сил, как и все сотоварищи. А под силами в широком смысле слова всегда разумеется и труд, который член посвящает на служение артели, и те имущественные взносы, которые он возлагает в общий капитал»".

Другое важное качество кооперативной собственности, отличающее ее от других видов собственности, заключается в реализации принципов прямой демократии в процессе ее имплементации и распоряжения. Кооперация является единственной формой социальноэкономической организации, последовательно воплотившей непосредственную демократию, ставшую обязательным условием существования. Как свидетельствует опыт международного кооперативного движения, любое нарушение этого принципа немедленно ведет к необратимым «мутациям», означающим фактическое перерождение кооперации: или в частно-капиталистическую, или административно-командную структуру, сохраняющую только внешнюю схожесть со своей первоприродой. Именно такую «метаморфозу» пережили европейская (в 60-х годах прошлого века) и советская кооперации, поставившую под сомнение перспективу развития кооперативной экономики ${ }^{* *}$.

В отличие от рационального эгоизма, получившего в классической теории экономики обоснование в качестве основного стимула экономической деятельности, не исключающего «войну каждого против всех», приумножение кооперативной собственности, напротив, предполагает безусловное сотрудничество.

Американский обществовед Ф. Фукуяма отмечает возможность капитализма продуцировать «социальный капитал», т.е. способность «людей работать вместе во имя общих целей в группах и в организациях». Однако, в центре общественной солидарности Ф. Фукуяма видит индивидуальный интерес, имеющий «ключевое значение для организации устойчивых бизнесструктур ${ }^{* * * *}$.

Одним словом, солидарность в представлении Ф. Фукуямы направляется от индивидуального к общественному: коллективному, групповому, корпоративному. В случае с кооперацией объединяющей доминантой становится совместная собственность, и вектор консолидации расположен прямо противоположно от общего к индивидуальному. Кооператор добровольно делегирует часть хозяйственного суверенитета обществу только в том случае, когда сумма выгод от этого превосходит сумму индивидуальных потерь.

Значение общественного начала в кооперации еще отчетливее следует из опубликованных взглядов российских интеллектуалов. Обобщая, можно выразить их общий смысл таким образом: мелкие собственники, составляющие социальную базу кооперации, могут иметь сколько угодно пороков и несовершенств, но объединив-

\footnotetext{
" Исаев А. Артели в России. Ярославль. 1881, с. 220-221

** См.: Егоров В.Г. Кооперация в современной России. СПб: Алетейя. 2013. с. 152-171

*** Фукуяма Ф. Доверие: социальные добродетели и путь к процветанию. М.: АСТ. 2004, с. 27, 580-581.
} 
шись, они обязательно придерживаются самых высоких нравственных стандартов".

Классик современной социологии Э. Дюркгейм отмечал, что действенная мораль, поддерживаемая в профессиональных группах и организациях, авторитетом коллективного сознания гарантирует высокий уровень дисциплины, солидарность и удовлетворение трудовым

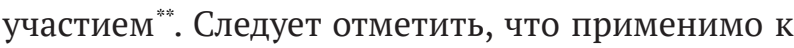
кооперации это положение социолога выглядит особенно актуально, так как источником коллективного сознания в дополнение к указанным Э. Дюркгеймом «индивидуальным чувствам» и «разделению труда» является коллективное целеполагание на сохранение устойчивого товарного производства.

Имея видовые отличия от капиталистической собственности, кооперативная собственность, в то же время не составляет альтернативу ее основополагающему институту: частной собственности и личному интересу и представляет антиономию социалистической, если считать таковой государственную, «общенародную». Кстати заметить, что в большинстве стран официальная статистика именно поэтому относит кооперативную собственность к разновидности частной.

Точно так же коллективный ее характер дал основание отечественным социалистам видеть в кооперации зачатки социализма, а в ленинской стратегии построения нового общества она заняла место промежуточной, переходной ступени к социалистической организации хозяйства.

Обе указанные позиции имели свои резонные основания, так как кооперация, продуцируя своеобразную форму собственности, все же не отрицает частную и одновременно являет собой разновидность общественной.

Сущностные качества кооперативной социально-экономической организации дают основания для ее цивилизационного позиционирования в «промежуточном» пространстве между капитализмом и социализмом. Однако, такой взгляд может быть признан релевантным только с точки зрения формальной логики, но не с позиции позитивного анализа места и роли ко- операции в общественном процессе. Вопреки чаяниям многих поколений энтузиастов кооперации таковая не может составлять, как капитализм и социализм, самостоятельной системы социальных отношений (по крайней мере в рамках индустриальной формации).

Во-первых, потому что кооперация в хозяйственной системе модерна имеет ограниченное своими природными качествами функциональное пространство, важнейшими из которых является доминирующее положение личности кооператора, совмещающего статус трудящегося и собственника. Первая основополагающая роль трудящегося, наделенного особыми умениями и навыками, обеспечивающими общественную значимость его мастерства в условиях массового производства, предполагает ограниченный потенциал машинизации кооперативного производства.

Вторая ипостась собственника накладывает ограничение на масштабы кооперативного предприятия. Согласно теории малых групп интересов, управленческий потенциал организаций уменьшается пропорционально увеличению ее численности. Тем более, размер кооперативной организации имеет принципиальное значение, с точки зрения владения и распоряжения членами кооперативной собственности и консолидации объединения в достижении результатов. Расширение масштабов организации, ведущее к появлению нескольких центров консолидации и непреодолимым препятствиям реализации статуса хозяина каждым членом общества, влечет утрату ее кооперативной природы ${ }^{* * * *}$.

Во-вторых, потому, что кооперация реализует групповые интересы и не может продуцировать консолидацию в рамках всего социума. Даже национальные кооперативные альянсы и союзы институционализируются только по мере того, как набирают необходимые функции, обеспечивающие жизнедеятельность низовой сети.

Попытки теоретиков спроектировать общество кооперативных ассоциаций, даже получившего свое название «кооптивизма», не имели успеха за пределами академических экзерциций.

Не всякая коллективная собственность яв-

\footnotetext{
"См.например: Энгельгардт А.Н. Из деревни. 12 писем. 1872-1887 гг. М.: Мысль, 1987, с. 351. Исаев А. Артели в России. Ярославль. 1881. С. 46.

** Дюркгейм Э. О разделении общественного труда. Метод социологии. М.: Наука. 1991. С. 14, $18,215$.

**** Егоров В.Г. Кооперация «третий путь». К теории вопроса. Челябинск: Рифей. 2003. с.
} 
ляется кооперативной и воспроизводит особый тип производственных отношений. Например, предшествующие рыночным отношениям традиционные формы коллективной собственности: общинной, артельной, имеющие внешнее сходство с феноменом модерна кооперативной, тем не менее, имеют иную природу.

Верное, до известных пределов, утверждение социалистов о том, что кооперация появляется на благодатной почве, подготовленной предшествующим развитием традиционных форм коллективного труда, не означает полной аутентичности социально-экономической сущности упомянутых реалий.

Один из основоположников современной социологии Эмиль Дюркгейм в известной работе «О разделении общественного труда» писал о «двух видах солидарности». «Первая,- писал он,- может быть сильна только в той мере, в какой понятия и стремления, общие всем членам группы, превосходят в числе и интенсивности те, которые принадлежат лично всякому из них. Она тем энергичнее, чем значительнее этот избыток. Но нашу личность составляет то, что в нас есть собственного и характерного, что отличает нас от других. Значит, эта солидарность возрастает в обратном отношении к индивидуальности»". «Совсем иначе обстоит дело с солидарностью,которую Э. Дюркгейм называет органической,производимою разделением труда. Тогда как первая требует, чтобы индивиды походили друг на друга, последняя предполагает, что они отличаются одни от других. Первая возможна лишь постольку, поскольку индивидуальная личность поглощается в коллективной; вторая возможна только, если всякий имеет собственную сферу действия, т.е. является личностью. Итак, нужно, чтобы коллективное сознание оставило открытой часть индивидуального сознания, для того чтобы в ней установились те специальные функции, которых оно не может регламентировать; и чем обширнее эта область, тем сильнее связь, вытекающая из этой солидарности»"*.

Традиционные формы коллективной собственности, основанные на солидарности первого вида, воспроизводят отношения, при которых общее полностью, или почти полностью, поглощает индивидуальное, и не продуцируют особый социально-экономический уклад, органично интегрируясь в доминирующую социальную систему. Напротив, кооперативная собственность, сохраняющая конструктивный потенциал традиции, выходит за рамки ее потенциальной мобильности, трансформируясь в новое качество, адекватное рыночной системе хозяйствования.

Кооперативная форма собственности зиждется на органической солидарности, вектор развития которой направлен на гармонизацию индивидуального и общественного. Кооператоры видели свое объединение прежде всего как средство повышения эффективности индивидуального предприятия. В этой связи, несмотря на выраженную собственную идентичность, кооперативная собственность не является альтернативой частной и может функционировать исключительно в рыночной экономике.

Как только большевики повернули от НЭПа, регенерировавшего рынок, к командной «плановой» экономике, кооперация, на которую В.И. Ленин возлагал большие надежды по обузданию капиталистической стихии, утратила свою актуальность, превратившись в один из инструментов «обобществления», а фактически подчинения мелких хозяйств централизованному администрированию. Последние остатки, отдаленно напоминающие о советском кооперативном укладе экономики, были упразднены в начале 1960-х годов, в связи с преобразованием промысловой кооперации в государственную систему местной промышленности.

Описанные «промежуточные» черты кооперации адекватно отражают стратегию общественного развития, сформированную теорией солидаризма. Теория солидаризма появилась в первой половине прошлого столетия в широком социологическом контексте дискуссии о способности капитализма к эволюционному самосовершенствованию. В противовес марксистскому утверждению «о неизбежном социалистическом будущем» ее автор Леон Дюги (1859-1928 гг.) утверждал, что классы, занимающие противоположное место в буржуазном способе производства, тем не менее могут выполнять «миссию», обеспечивающую солидарность и «гармонию общества», благодаря которой удастся преодо-

\footnotetext{
" Дюркгейм Э. О разделении общественного труда // e-libra.su., с. 3

** Там же, с. 4.
} 
леть антагонистические противоречия капитализма посредством мирных реформ.

Институт частной собственности Л. Дюги трактовал как обязанность, реализуемую в интересах общества («социализация собственности», «социальный долг»).

Презентация института частной собственности как социальной функции обусловила логику Л. Дюги, утверждавшего возможность перестройки общества на основе синдикалистского федерализма, позволяющего конституировать представительство объединенных в профсоюзы граждан, регулируемого системой внутренних договоров. Такое устройство общества, по мнению основоположника солидаризма, должно было обеспечить «правовой плюрализм» и децентрализацию политической власти (в том числе ее агрегирование у классов, являвшихся носителями социальной силы).

Последователями солидаризма в Германии после Первой мировой войны стали Генрих Пеш и Густав Гундлах, которые полагали возможным устройство общества на основе подлинного солидарного объединения людей по образцу «природных сообществ»".

Идеи «солидаризма» явились питательной средой для практики «социального рыночного хозяйства», благодаря которой Германии удалось не только восстановить свою экономику после поражения во Второй мировой войне, но и вернуться в «клуб» передовых стран мира ${ }^{* *}$.

Немецкий экономический порядок, ставший залогом успеха восстановления разрушенного хозяйства, основывался на координации уровней делегирования «экономической свободы» между субъектами экономической де-

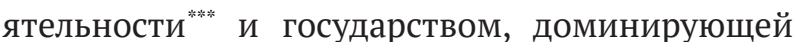
роли последнего в продуцировании «солидарной экономики», ориентированной «на единую упорядочивающую идею», посредством которой достигается «взвешенное равновесие различающихся между собой интересов общества и индивидов, социальных групп и индивида», «рассредоточивание политической и экономической власти»"****.

Суть концепции «социальной рыночной экономики» заключается в достижении через сложившийся в обществе консенсус (доминирующей идеи достижения всеобщего блага), создание механизма государственного управления экономикой с целью купирования «уязвимых мест модели рыночного хозяйства»: «неограниченного стремления к получению прибыли, порождающего «возникновение социального климата, при котором теряются такие ценности, как взаимовыручка, способность прийти на помощь, понимание другого, чувство сопричастности и социальное мышление, обеспечение достойных человеческих условий труда и др.» Механизм социального рыночного хозяйства строится на конкуренции, подчиненной определенным нормам, «регулирующим ее качество, т.е. она не ведется недобросовестными средствами, не основывается на обмане, не связана с дискриминацией и не приводит к разорению, и когда экономическое поведение в целом вписывается в рамки установленных обществом правовых норм, обеспечивающих гарантию достоинства личности и соблюдение социальной справедливости» ${ }^{* * * * * *}$.

В отношении либерального и административного, социально-рыночный экономический порядок составляет промежуточное положение и назван его архитекторами «третий путь». Механизм реализации социального рыночного порядка, как и теоретические взгляды Л. Дюги, предполагал «целый ряд положений по обеспечению социальной функции» частной собственности. «Наиболее конструктивной особенностью, проводимой в ФРГ политики в области собственности является противодействие необоснованной концентрации ее в руках государства, форм и частных лиц путем наращивания общего количества собственников»******.

На реализацию такой стратегии направлена в том числе кредитная политика, создающая режим наибольшего благоприятствования финансированию малых экономических форм. На ин-

" Окара А. Социальная солидарность как основа нового «миростроительного проекта»//Синергия. № 9. 2010 . С. 7.

*** Ламиерт Хайнц. Социальная рыночная экономика. Германский путь. М.: Дело, 1993, С. 7.

**** Там же. С. 27

***** Там же. С. 37

****** Там же. С. 37

******* Там же. С. 75,76 
ституты мелкого кредита: сберегательные кассы и кредитные банки приходится до четверти всей кредитной системы Германии".

Закон 1957 г. «О запрете ограниченной конкуренции» предусматривает право государства препятствовать соглашениям, «заключаемым предприятиями или объединениями предприятий во имя единых целей и решений, ограничивающих конкуренцию и способных влиять или на производство или на рыночный оборот товаров или промышленных изделий»"*.

Социальная рыночная экономика создает наиболее благоприятные условия для развития кооперации. На сегодня намецкая кооперация является одной из наиболее развитых в мире. Каждый пятый немец является членом кооперативных объединений или связан с их деятельности. На федеральном уровне интересы кооперативных предприятий предствляют три структуры: Союз Германских Народных Банков и Банков Райффайзен (BVR), Германский Союз Райффайзен (DVR), обслуживающий сельские товарищества, и Центральный Союз промышленных Групп (ZGV), объединяющий промысловые артели

Воплощение в общественной практике идей солидаризма, предполагающего гармонизацию интересов всех субъектов хозяйственной деятельности, обусловлено реализацией механизма, препятствуюшего безусловному доминированию одного социально-экономического уклада, или, точнее сказать, его развитию, исключающему функционирование других экономических сущностей. Успех в создании такого механизма напрямую зависит от характера и содержания осуществляемой модернизации. Например, определяющим западную цивилизацию качеством модернизационных процессов, явилось форсированное становление крупного капитала, источниками опережающего роста которого были активы, полученные в результате крестовых походов, колониальной экспансии, или, как в случае с Германией, перенаправления юнкер- ского капитала.

Однако даже в рамках собственно западного мира исключение составляет его «периферия». Так, становление индустриального порядка Швеции не сопровождалось вытеснением мелкого и даже кустарно-ремесленного производства из экономики. К середине 1950-х годов среднее число рабочих на одном предприятии с 1913 года практически осталось неизменным (в 1913 г.- 39 чел.; 1956 г. - 41 чел.) ${ }^{\text {s.ststs }}$. Общий удельный вес самых мелких предприятий (с числом рабочих до 10 чел.), так же изменился незначительно. В 1913 г. они составляли 51,1\% общего количества, а в 1955 г.- 47,3\% . Сохранение мелких экономических форм происходило не в ущерб развитию крупной промышленности, и совсем не исключало образования монопольных союзов, но стало возможным за счет создания благоприятных условий их росту в сферах экономики, не адекватных массовому капиталоемкому производству. «Многие обслуживающие предприятия,- пишет К.Х. Херманссон,- часто осуществляют свою деятельность в отраслях, где крупный капитал не стремится устанавливать свое господство, потому что этот вид деятельности не рассматривается как достаточно прибыльный или требующий личных вкладов (умений ручного труда - авт.), которые может сделать только мелкий предприниматель» ${ }^{\text {messesta }}$. Комплементарные условия развития мелкой собственности способствовали росту кооперативного сектора Швеции. Удельный вес кооперативных предприятий в этой стране с 1931 по 1951 гг. увеличился с 4,2\% до 7,9\%, а их оборот вырос с 6,4\% до 11,4\% общего оборота, численность занятых в кооперативном секторе - с 2,9\% до $6,0 \%^{\text {********** }}$.

Кооперация, не имеющая (в индустриальном обществе) собственного системообразующего потенциала, испытывает влияние доминирующих социально-экономических отношений. Именно в силу этого обстоятельства кооперативные предприятия, составляющие

\footnotetext{
"Там же. С. 87,88

"“" Там же. С. 121.

"swn Кооперативы в Германии//geolike.ru

Hermansson C.H. Koncentration och storfÖretag. Stockholm. 1959, sid. 22.

"wamasat

"astats Там же, с. 143-144

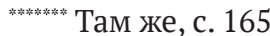


узкий сегмент, интегрированный в «чужеродный» экономический порядок, неизбежно аккумулируют качества господствующей социальноэкономической системы. Например, в обществах с либертарианской доминантой, кооперация чаще претерпевает мутацию и трансформируется в организационные формы, имманентные существующему социально-экономическому устройству. Не испытывая такого «давления», в $\mathrm{XX}$ веке наиболее внушительных масштабов достиг кооперативный сектор капиталистической периферии: Италии, Испании, Ирландии и т.д., и развивающихся стран".

Доказательством «пагубного» влияния господствующей социальной системы стало огосударствление советской кооперации.

Из представленного логично предположить, что высокий уровень развития кооперации Германии является следствием благоприятных социально-экономических условий, продуцированных немецким опытом реализации солидаризма как воплощенной в социальноэкономическом порядке идеи достижения общего блага.

Особое место идеи солидаризма получили в отечественной философской и экономической мысли. Значительная часть его сторонников искала истоки социальной интеграции и проектирования в духовных, православных скрепах"*.

Надежды духовной консолидации значительно фрагментированного общества на основе христианских ценностей и сегодня воодушевляют сторонников формирования российской идентичности. Однако духовные основания, действительно игравшие и наверняка еще способные сплотить общество в сложные моменты истории, не могут являться единственным и тем более абсолютным системообразующим фактором.

В условиях незрелости гражданского общества (если о таковом вообще уместно упомянуть), слабости профсоюзного движения и т.д., средства формирования социального консенсуса, о которых говорил Л. Дюги, не выглядят убедительными, поэтому отечественный дискурс солидаризма в значительной мере актуализировался в связи с двумя институтами: государства и кооперации, отражающими два социетальных направления общественного развития: доминирования власти и артельности народного этоса"**a. «Полномочия власти и степень ограничения частных прав,- в представлении одного из теоретиков солидаризма Г.К. Гинса,- должно соответствовать поставленной цели» воплощения идеи солидаризма в социальном порядке. Его архитектура в концепции Г.К. Гинса выглядела «как сложное сооружение», «поднимающееся от индивидов через ряд всевозможных групповых организаций (в том числе кооперативных авт.) - к государственной вершине, но опирающейся на самостоятельность и самоопределение индивидов и групп» ${ }^{* * * *}$.

Выполняя функцию координатора групповых интересов, государство опирается на «особую систему права и хозяйства». «Право, которым будет скрепляться система солидаризма, можно назвать координирующим (согласительным или регулятивным) правом, а хозяйство солидаризованным, или координированным хозяйством»"**as. Правовые границы,- по мнению Г.К. Гинса, должны не просто ограничивать свободу, «как это принято в частном праве», но прежде всего быть ориентированы на подчинение интересов частных общественным.

Однако, и в таком прочтении суть спроектированного российскими солидаристами порядка представлена не исчерпывающе. Главное его содержание заключалось в принципе, согласно которому должно осуществляться государственное регулирование баланса «частных и публичных интересов». Такое регулирование, в проекте солидаризма, по Г.К. Гинсу, воспроизводило естественно сложившееся соотношение индивидуальных и коллективных интересов в кооперации. Знаток отечественной кооперативной традиции, Г.К. Гинс полагал, что «пределом и условием» реализации интересов общества «являются выгоды самих участников». Консенсус частного и публичного мог состояться только в случае, когда сумма выгод от такого консенсуса для «ор-

\footnotetext{
"Егоров В.Г.

${ }^{* *}$ См. Фотиев К. Солидаризм и христианство // Посев. № 9. 2002. С. 37-39 и др.

***. См. например: Аверьянов В. Русская артель. Невостребованный опыт: из прошлого в будущее? // Свободная мысль. № 3. 2014. С. 107-124.

**** Гинс Г.К. Руководящая идея нашего века // Портрет солидаризма. Идеи и люди. М.: Посев. 2007, С. 82

**:**** Tам же. С. 88
} 
ганизации групп» превышала сумму потерь от утраты некоторой части собственных интересов*. Чтобы прояснить свои взгляды по этому поводу, Г.К. Гинс иллюстрировал их примером с дорожным движением, при котором всеобщее доступное регулирование выгодно всем его участникам. «Основная идея координационного (регулятивного) права, отвечающая за его название, заключается в том, что государство не может навязывать частному хозяйству те цели, которые ему чужды, и приносить индивидуальные или групповые интересыв жертву общему благу иначе, как в порядке исключительных законов, оправдываемых исключительными обстоятельствами. Оно может допускать только такое ограничения, вернее, такое соподчинение или согласование прав в интересах общей выгоды приносят одновременно выгоду и тем, кто подвергается ограничениям»**.

«Солидаризованное хозяйство», как полагали его архитекторы, должно строиться на рыночных основаниях, предполагающих незыблемость частной собственности и конкуренции. «Государство не должно препятствовать соперничеству групп, отстаиванию каждою из них своих интересов. Это естественно, неизбежно и даже необходимо для прогресса. Но государство не может оставаться безучастным. Оно не должно допускать таких форм борьбы, которые вредят государству в его целом и, следовательно, в конечном результате вредны и для враждующих групп»"***.

Поощряя конкуренцию, государство как регулирующий центр, по мнению Г.К. Гинса, должно купировать ее неконструктивные проявления, отражающие крайние формы рационального эгоизма, таким образом «обращаться в орган активного содействия хозяйственному благополучию страны».

Еще одним стержневым моментом «солидаризованного хозяйства» в планах его проектантов стала новая, или вернее сказать, дополнительная функция государства, в некоторой степени альтернативная административной, а именно хозяйственная. Государство в системе нового хозяйственного порядка должно трансформироваться в субъект рыночной экономики, выступая институтом, гармонизирующим общественные, групповые и индивидуальные интересы и создавая «механизм открытого доступа» к факторам производства для всех акторов хозяйственной деятельности.

«Солидаризм отрицает как пассивность либерального государства, так и самоуверенную претенциозность государства социалистического» и «не дает государству права регулировать хозяйство, не превращает хозяев в чиновников, не уничтожает собственность и конкуренцию. Но государство перестает быть только политической силою. Оно определенно ставит своей задачей содействовать производительным силам страны и согласовывать интересы предпринимателей, рабочих и потребителей» ${ }^{* * * *}$.

По мнению Г.К. Гинса кооперация, испытывающая деструктивное влияние капиталистической конкуренции, не имеющей нормативных и правовых ограничений, имманентна порядку, спроектированному солидаристами. Солидарность, являвшаяся природным качеством объединений мелких собственников, позволяет значительно проще интегрировать их в «солидаризованное хозяйство». «Солидарность, воспитываемая кооперацией,- требует некоторого отречения от индивидуалистической психологии, она приучает к коллективным действиям, и в то же время она не создает коллективизма, поглощающего всецело отдельных лиц и лишающего их индивидуальности»; «участие в кооперативе развивает ... сознание общности интересов и необходимость соблюдения их в порядке сотрудничества и взаимной дисциплины» ${ }^{* * * * *}$.

Кроме того, кооперация, являвшаяся (по К. Марксу) «паллиативом» в капиталистической хозяйственной системе, должна стать главным или, по крайней мере важнейшим укладом экономического порядка солидаризма. Другой солидарист профессор А.Д. Билимович указывал, что «...кооперативный сектор будет играть настолько крупную роль, что смешанное многосекторное народное хозяйство будущей России ста-

\footnotetext{
"Там же. С. 89.

** Там же. С. 91.

**** Там же, С. 92.

***** Там же, С. 93, 94

**:**** Taм же, С. 106
} 
нет в значительной мере «кооперативным»"..

Взгляды солидаристов, основанные на теоретическом анализе только намечавшихся признаков социально-экономической перспективы, оказались во многом пророческими. Современные тенденции становления постмодерна позволяют предположить, что кооперативная форма организации претендует на один из ведущих его секторов.

С высоты минувших десятилетий солидаристам удалось критически оценить опыт дореволюционного отечественного кооперативного строительства и актуализировать, в связи с этим, важное теоретическое положение. Кооперация, являющаяся одним из закономерных направлений концентрации мелкого производства, не может быть использована как инструмент реализации даже самых прогрессивных идей в отсутствии объективных предпосылок. Созданные усилиями энтузиастов с целью противодействия пауперизации населения или осуществления социальных экспериментов, кооперативы оказывались нежизнеспособными. Пролетарские слои населения, обычно привлекаемые в насаждаемые «сверху» кооперативы, были не способны генерировать кооперативную собственность и мотивацию, основанную на гармонизации статуса кооператоров, одновременно являющихся собственниками и работниками. «Первый 30-летний период с 1865 по 1895 гг.,- писал А.Д. Билимович, - был периодом первых кооперативных опытов. Многие из основанных за это время кооперативов просуществовали недолго вследствие отсутствия подготовленных руководителей и кооперативных навыков у населения. Основываемые сверху, они часто встречали непонимание, индифферентизм и иногда даже враждебное отношение со стороны крестьянской массы. Задерживалось развитие кооперации также низким хозяйственным уровнем крестьянства. Крестьяне брали ссуды, но не платили паев, которые вычитались из ссуд; ссуды не возвращались и по много раз переписывались» ***.

В «солидаристском хозяйстве» кооперация по мнению его теоретиков должна представлять исключительно экономическую сущность, без наделения ее несвойственными политическими функциями и «культурными целями». «Согласно этим принципам,- писал А.Д. Билимович,- новые кооперативы и их союзы должны быть: свободными объединениями отдельных хозяев и их хозяйств или их объединений для той или иной хозяйственной цели..., осуществляемой сообща при помощи соединения для этого труда и средств своих членов и общего ведения дела через посредство органов, свободно избираемых всеми членами объединения» ${ }^{* * * *}$.

Концепция солидаризма содержит положение, важное не только с точки зрения функционирования кооперации в условиях «капиталистического окружения», но и определения перспективы ее развития. В артикуляции профессора А.Д. Билимовича это положение формулируется так: главной целью объединения «является не прибыль на вложенный капитал (выделено авт.), а обслуживание промыслового или потребительского хозяйства своих членов», а «получаемый чистый плюс, кроме рыночного ссудного процента, уплачиваемого поставщикам, и небольших отчислений в запасный капитал, распределяется между членами... не пропорционально паевым взносам, как это имеет место в капиталистических обществах, а пропорционально участию в операциях объединения (выполняемому труду, производимым продуктам и т.д.)»*****

Устранение из практики кооперации распределения дохода по величине паевого капитала, препятствовало капиталистическому перерождению кооперативных предприятий и устанавливало преграду размыванию сущностных качеств, основанных на гармонизации труда и собственности и исключающих смещением этого природного баланса в любую из сторон. Так же как капитализация паевых взносов ведет к утрате кооперативной сущности, доминирование эгалитаризма (чаще наблюдаемое в трудовых артелях) нарушает строй кооперативных предприятий, базирующийся на особой мотивации хозяйственной деятельности, направленной на укрепление материального статуса участников.

\footnotetext{
" Билимович А.Д. Кооперация в России до, во время и после большевиков. Frankfurt/main. 1955, С. 105

** Билимович А.Д. Кооперация в России до, во время и после большевиков. Посев. 1955, С. 7.

***: Там же. С. 106.

***** Там же.
} 
Поддержанию указанного баланса труда и собственности способствует другой отмеченный солидаристами принцип кооперации: «каждый член независимо от числа его паев, имеет один голос»". Кооперативная демократия отрицает возможность расширения прав в управлении и распоряжении совместным предприятием в связи с увеличением паевого капитала, вследствие чего исключается доминирование в кооперации наиболее крупных собственников и вообще аккомулирование «силы» в руках меньшинства.

Важнейшим положением, обеспечивающим жизнеспособность кооперативного сектора, «солидаристы» считали адекватное определение места и роли наемного труда в объединениях. Развитие кооперативных предприятий, порождающее потребность в специалистах необходимого профиля, не исключает участие в их деятельности наемных работников. Однако количество наемных работников должно быть таким, чтобы доля стоимости продуктов и услуг, создаваемых не пайщиками, не превышала доли вновь производимой стоимости членами, а кооперация труда не доминировала над кооперацией собственности"*

Солидаризм в современном нелиберальном дискурсе рассматривается в более широком социальном контексте как стратегия, позволяющая преодолеть становящиеся преградой на пути прогресса черты «модерна», связанные с доминированием индивидуализма «человека экономического». «В условиях глобального транзита,- пишет А. Окара,- на первый план выходит вопрос о согласовании и солидаризации интересов, ценностей и потенциалов всех участников общественных отношений, поэтому социальная теория солидаризма, для которой этот вопрос является ключевым, обретает новое звучание и вполне реальные перспективы востребованности»***.

Малые группы с консолидированными социально-экономическими интересами (каковыми, безусловно, являются кооперативные организации) в постиндустриальном мейнстриме, об- ретают «новую субъектность», обусловленную этерализацией их коммуникативного и интерактивного потенциала. Роль «малых социальных» групп, коллективов, сообществ в целом и кооперативной организации, в частности, преодолевает определенные К. Марксом в условиях восходящего развития капитализма рамки «паллеатива», находящегося в лучшем случае в параллельном с буржуазным потоке социальной эволюции.

В связи с актуализацией социальной реальности, архитектура которой выстраивается на паттернах постмодерна, малые группы «обретают возможность несимметрично влиять на глобальные процессы» ${ }^{* * * *}$. Кроме того, постиндустриальная социальная новелла порождает обусловленность механизмов самоорганизации, основанных на этических и онтологических посылах, выходящих за рамки модерна.

Не просматриваемая даже в видимой перспективе возможность воплощения в жизнь теоретических проектов солидаристов в период их создания, сегодня выглядит не так призрачно. Авторитетные научные школы современности говорят о приближении экономического порядка «посткапитализма» ${ }^{* * * * *}$.

Причем его основные черты практически аутентичны тем, которые обосновывали архитекторы солидаризма. В качестве основополагающих черт грядущей экономической системы современные исследователи называют децентрализацию собственности, которая происходит не столько за счет экспроприации крупного капитала" , сколько благодаря демократизации собственности, возможной вследствие реактуализации малых экономических форм и возрастания общественного значения выходящих из-под контроля капитала и государства носителей интеллектуальной собственности. «Что бы ни пришло на смену капитализма,- пишет Рэндалл Коллинз,- ему прежде всего придется заняться полномасштабным перераспределением частных состояний и активов, генерируемых капиталистическим бизнесом и финансовыми

\footnotetext{
" Там же. С. 106

*** Там же.

**** Окара А. Социальная солидарность как основа нового «миростроительного» проекта // www.perspektivy.info.

****** Там же.

**:**: См.: Есть ли будущее у капитализма? М.: Ин-т Гайдара. 2015

******* Хотя и такие меры государственного регулирования не исключаются
} 
манипуляциями. Перераспределение будет в пользу большей части населения, лишившейся к тому времени работы из-за компьютеризации и механизации, включая многих нынешних менеджеров, юристов и «креативных» специалистов. Программа перераспределения создает повод для взятия под контроль финансовых институтов, которые сейчас удерживают капитализм на его гибельном пути. Вероятно, эти посткапиталистические институты будут менее централизованы, чем наблюдалось в классических экспериментах XX века с государственным социализмом»".

Как и теоретики солидаризма, современные экономисты определяют общественную перспективу «посткапитализма» между капитализмом и социализмом, опыт функционирования которых выявил их малопривлекательные черты. «В результате грядущие столетия,- пишет Р. Коллинз,- увидят колебания между двумя типами постэкономических систем от капитализма к социализму и, возможно, обратно к капитализму»***.

В противоположность неолиберальным воззрениям, по мнению ученых, разделяющих точку зрения «о конце капитализма», в экономике будущего будет восстановлена полноценная координирующая роль государства****.

Централизованная плановая экономика будущего может быть авторитарной, а может и не быть таковой; но, определенно, она будет располагать всей компьютерной технологией, роботами, средствами координации и наблюдения для того, чтобы каждодневно и глубоко присутствовать в обществе, хотя бы и в самых благих целях ${ }^{* * * * * *}$

О возможности избежать при регенерации координирующей функции государства повторения авторитарного советского опыта, опасность которого не исключают современные исследова- тели, говорили теоретики солидаризма. Не авторитарная, но координирующая (регулирующая) роль государства возможна в случае переориентации управления экономикой от собственных интересов к интересам субъектов хозяйственной деятельности. В новом прочтении солидаризма функция координации предполагает в меньшей степени администрирование (кроме случаев нанесения ущерба общественным интересам) и в большей - создание благоприятных условий и гармонизации интересов всех субъектов экономики.

Компьютеризация и информатизация в таком контексте могут предоставить дополнительные возможности в выстраивании управления народнохозяйственным комплексом ${ }^{* * * * * * *}$.

Таким образом, перспектива развития мирового кооперативного сектора в значительной мере аллогенна либертарному мейнстриму капитализма, совпадает с наметившимися трендами «посткапитализма», концептуальные основы которого заложили теоретики солидаризма. Природные качества кооперации наиболее последовательно отражают актуальное представление социально-экономического будущего, черты которого проявляются в современных тенденциях цивилизационного развития.

Зародившись на стадии перехода общества от традиционного к индустриальному состоянию, и воплотившая конструктивный потенциал традиции, кооперация не только не утратила своей общественной значимости в эпоху модерна, но органично «встраивается» в архитектуру грядущего «посткапиталистического» общественного порядка. При этом сама благодаря природному потенциалу, обусловленному внутренними диалектическими противоречиями, продолжает совершенствоваться, впитывая инновации, обусловленные актуальными тенденциями цивилизационного развития.

\footnotetext{
" Коллинз Р. Средний класс без работы. Выходы закрываются // Есть ли бужущее у капитализма? М.: Ин-т Гайдара. 2015., С. 105-106

** Там же, С. 107

*⿻*⿲二丨匕 Ссылаясь на негативный опыт советского авторитаризма, многие западные исследователи вслед за Л. Хайеком (Дорога в рабство) видят в регенерации координирующей роли государства источник новых социальных деструкций.

***** Коллинз Р. Указ. соч., с. 108

****** Симонов К. Магия цифры // Ведомости. № 165 (4400). 2017.
} 


\section{Библиографический список}

1. Аверьянов В. Русская артель. Невостребованный опыт из прошлого в будущее? // Свободная мысль. № 3. 2014. С. 107-124.

2. Билимович А.Д. Кооперация в России до, во время и после большевиков. Frankfurt/main. Посев. 1955.

3. Бланден Э. Социальная солидарность и социальный капитал // http://home.mira.nev-andy/works/

4. Гинс Г. К. Руководящая идея нашего века // Посев. № 7. 2003. С. 22. № 9. 2003. С. 28-32

5. Гинс Г.К. Настоящее и будущее солидаризма // Посев. № 7. 2002. С. 30-36.

6. Гинс Г.К. Современный капитализм и предстоящая эпоха (философия солидаризма) // Портрет солидаризма. Идеи и люди. М.: Посев. 2007, С. 82

7. Гофман А.Б. Солидарность или правила, Дюркгейм или Хайек? О двух формах социальной интеграции. Социологический ежегодник. 2012. Сб. научных трудов. М. ИНИОН РАН. 2013. С. 97-167.

8. Дуглас Н. институты, институциональные изменения и функционировние экономики. М.: Начало. 1997.

9. Дуглас Н. понимание процесса экономических изменений. М.: Излдательский дом ГУ-ВШЭ. 2016.

10. Дюркгейм Э. О разделении общественного труда. Метод социологии. М.: Наука. 1991.

11. Егоров В.Г. Кооперация «Третий путь» (к теории вопроса). Челябинск: Рифей. 2003.

12. Егоров В.Г. Кооперация в современной России. СПб: Алетейя. 2013.

13. Идеология и философия солидаризма. Материалы действующего семинара. Вып. 9. М.: Научный эксперт. 2010.

14. Исаев А. Артели в России. Ярославль. 1881.

15. Ламперт X. Социальная рыночная экономика. Германский путь. М.: Дело. 1993.

16. Левицкий С. А. Свобода и ответственность. «Основы органического мировоззрения» и статьи о солидаризме. М.: Посев. 2003.

17. Окара А. Социальная солидарность как основа нового «миростроительного» проекта // Синергия. 2010. № 9. С. 3-18.

18. Олсон М. Логика коллективных действий: Общественные блага и теория групп. М.: Фонд экономической инициативы. 1995.

19. Портрет солидаризма. Идеи и люди. М.: Посев. 2007.

20. Пушкарев Б. Российский солидаризм: вчера и сегодня // Посев. № 4. 2003/posevru@online.ru

21. Уильямсон О. Экономические институты капитализма. СПб: Лениздат. 1996.

22. Фукуяма Ф. Доверие: социальные добродетели и путь к процветанию. М.: АСТ. 2004

23. Хайек Ф.А. Дорога к рабству. М.: Экономика. 1992.

24. Шумпетер И. Капитализм, социализм и демократия. М.: Экономика. 1995.

25. Энгельгардт А.Н. Из деревни. 12 писем. 1872-1887. М.: Мысль. 1987. 